\title{
REAL TIME POLYMERASE CHAIN REACTION (RT-PCR) FOR DNA PIG CONTAMINATION IDENTIFICATION SAUSAGE IN SIX DISTRICT PANDEGLANG BANTEN
}

\section{(IDENTIFIKASI KONTAMINASI BABI PADA SOSIS DENGAN MENGGUNAKAN REAL TIME POLYMERSE CHAIN REACTION (RT-PCR) DI 6 (ENAM) KECAMATAN KABUPATEN PANDEGLANG BANTEN)}

\author{
Hadi Susilo \\ Universitas Mathla'ul Anwar Banten \\ Email: hadisusilo1973@gmail.com
}

\begin{abstract}
Sausage is a meat product processed that is popular food especially in Pandeglang, Banten Province. The importance of halal certificates or the existence of the MUI (Indonesian Ulama Council) halal logo for processed meat products makes Muslim people confident to consume them. The aim this research was to identify pig DNA contamination in sausage products in six districts in Pandeglang without the MUI halal labels using RT-PCR (Real Time-Polymerase Chain Reaction). RT PCR that can calculate to pig to fill these sample free from pig contamination. This research was divided into two stage, the first stage is extracted or carried out DNA and the second stage is RT PCR analysis. The results of the DNA purity test on sausage samples had DNA purity values of 1.84-1.9 $\left(\mathrm{A}_{260} / \mathrm{A}_{280}\right)$ and resulted in sample concentrations ranging from 37.8 to $102.5 \mathrm{ng} /$ $\mu 1$. The only amplification on the FAM curve was in the positive control pig. the Cq value ranges from 30 - 31.29. The results of RT PCR on sausage samples in the district area in Pandeglang Banten did not detect the presence of pig DNA.
\end{abstract}

Keywords: DNA, Halal, Real Time Polymerase Chain Reaction, Sausage

Abstrak: Kabupaten Pandeglang tempat di Provinsi Banten memiliki pusat jajanan yang menyediakan sosis bakar. Sosis yang dijajakan seringkali menyebabkan kecurigaan masyarakat akan kehalalannya karena seringkali sudah tidak ada kemasan dan kemasan sosis yang dijajakan juga tidak berlogo halal MUI. Upaya yang dilakukan dalam identifikasi adanya cemaran babi pada sosis bakar yang beredar di pusat jajanan di 6 kecamatan di Kabupaten Pandeglang belum dilakukan. Pada penelitian ini akan dilakukan identifikasi ada atau tidaknya cemaran DNA (Deoxyribonuclic Acid) babi menggunaan Real TimePolymerase Chain Reaction (RT-PCR). Hasil uji kemurnian DNA pada sampel sosis di pusat jajanan di wilayah Kabupaten Pandeglang memiliki nilai kemurnian DNA 1,84-1,9 $\left(A_{260} / A_{280}\right)$ dan menghasilkan konsentrasi hasil sampel berkisar 37,8 - 102,5 ng/ $\mathrm{l}$. Satusatunya amplifikasi pada kurva FAM hanya ada pada kontrol positif babi, nilai Cq berkisar 30 - 31.29. Sosis Kabupaten Pandeglang tidak terdekteksi adanya kandungan DNA babi, hal itu ditunjukkan dengan tidak adanya kurva amplifikasi pada chanel FAM.

Kata Kunci: DNA, Halal, Real Time Polymerase Chain Reaction, Sosis 


\section{INTRODUCTION}

Pandeglang Regency is an area in Banten Province which has many food centers that provide grilled sausages as snacks favored by the community (Rostianti et al. 2020). The sausages that are sold often cause public suspicion about the level of their halalness because there is often no packaging and the sausage packaging that is marketed does not have the MUI halal logo.

From these factors, it is necessary to conduct tests to answer public suspicions about the presence of pork contamination in grilled sausages without the halal logo. Efforts to identify the presence of pork contamination in grilled sausages circulating in food centers in Pandeglang have not been carried out. In this study, identification of the presence or absence of pig DNA (Deoxyribonuclic Acid) contamination using Real Time-Polymerase Chain Reaction (RT-PCR).

The method of identification pig DNA contamination using RT-PCR. RT-PCR has a high level of sensitivity and specificity. RT-PCR testing has been widely used by several researchers. Cai et al. (2012) were able to detect and calculate the amount of pork and beef gelatin in the gelatin mixture using the RT-PCR method. Other researchers have also examined and detected the presence of pig DNA contained in processed foods using RTPCR (Amqizal et al. 2017).

The aim this study for identified sausage products from pig contamination without halal label from food centers in Pandeglang Banten using RT-PCR method.

\section{METHOD}

\section{Sample Preparation}

The sample collection in this study was carried out, using the accessible population method, namely the population that can be reached by researchers (Millani, 2016). Samples were taken at hawker centers in Pandeglang Regency in 6 (six) sub-districts in Pandeglang Regency that were reached by researchers.

Sampling in this study using purposive sampling method, namely determining the sample with certain considerations (Sugiyono, 2005). In this study, the samples tested for Real Time PCR were processed meat products (sausages) that did not have the MUI halal label sold by grilled sausage hawker vendors. Because sausage products that have an MUI halal label on their packaging are considered halal.

\section{Isolation of DNA Samples and Control DNA}

DNA isolation in this study was carried out on pork, beef sausage and 10 samples of grilled sausage without MUI halal label. The method used in this study is the Phenol Chloroform DNA extraction method which is commonly used in laboratory procedures (Kamaliah, 2017). The DNA extraction stage using the Phenol Chloroform method consists 
of three processes, namely, the process of cell lition, purfication and precipitation. Here's the process:

First, the samples were weighed were sausages without halal labels and $200 \mathrm{mg}$ of pork each then put in a $2 \mathrm{ml}$ tube. The cell lysis process is the first process of DNA extraction starting with destroying the cell membrane by adding the $2.5 \mu$ proteinase $\mathrm{K}$ enzyme and $1 \mathrm{ml}$ food lysis buffer to bind lipids so that the cell membrane is damaged and all cell contents come out by the incubation process using a Thermo Shaker at $60^{\circ} \mathrm{C}$ during 30 minutes at a speed of $1000 \mathrm{rpm}$, this process causes the DNA to mix with other cell macromolecules, to reduce precipitation, the sample is cooled at room temperature and then put into an ice block after incubation.

The second stage of the DNA extraction process is the purification of DNA purification from cell macromolecules by adding $500 \mu \mathrm{l}$ of Chloroform to bind macromolecules other than DNA such as proteins, lipids, and carbohydrates. Then centrifuged at a speed of $2500 \mathrm{xg}$ for 5 minutes (the main principle of centrifugation is to separate substances based on molecular density) at this stage DNA and water are separated from other organic materials after disincentugation.

The third stage of the DNA extraction process is precipitation, this process is carried out to draw water from the DNA. With care, the clear layer of the tube that has gone through the two previous stages is removed with the help of a pipette without touching the precipitation that occurs at the bottom of the tube, then put into a $2 \mathrm{ml}$ tube containing $500 \mu \mathrm{l}$ of Chloroform, then vortexed for 15 seconds for a homogeneous process of the solution and centrifuge at $14,000 \mathrm{xg}$ for 15 minutes.

\section{The results of DNA isolation were analyzed with a UV Spectrophotometer}

The isolated DNA was then analyzed with a UV spectrophotometer for DNA. The analysis process was carried out by selecting nucleic acid on a UV DNA spectrophotometer screen. Then the port sample is cleaned with sterile tissue. DNA solution was prepared $1 \mu 1$ in the sample port as a blank and analyzed. The identity of the sample was entered into the port sample which had previously been cleaned with sterile tissue. Analysis was carried out to see the purity of DNA. Furthermore, DNA was analyzed with a wavelength of $260 \mathrm{~nm}$ and $280 \mathrm{~nm}$.

\section{DNA by RT-PCR}

Is a process of enzymatic DNA multiplication (replication) to obtain DNA replication in large quantities and in a short time. The working principle of PCR is to multiply specific DNA segments starting with dNTP-dNTP attachment in a thermal reaction following the PCR primary reference (Russel 1994). In this context, PCR can be used to detect the content of species in the expected food. This is needed for the DNA source to be amplified. DNA contains the segment we want and the template DNA must be specific enough to be easily 
initiated by the primer at the time of amplification. If the initial sample is in the form of RNA, it has to be reversed first to become cDNA to be used as the next template.

Primary: Oligonucleotide, 18-30 bases. Primary function: as a reference in the process of initiation and amplification of DNA sequences. Primers are synthetic nucleotide strands that specifically clamp the area to be amplified and have the potential to hybridize with the two target chains in the template DNA. DNA Polymerase, namely the polymerse enzyme (Thermus aquaticus), serves to attach dNTP to DNA sequences during the annealing stage in the DNA polymerization process. dNTP: a collection of bases that make up DNA. The function of dNTP: as a nucleotide donor in the polymerization process and extension of the DNA strand when amplified.

There are 4 types of bases: dATP (deoxyadenosin triphosphate), dTTP (deoxythymidine triphosphate), dGTP (deoxyguanosine triphosphate) and dCTP (deoxycytidine triphosphate). Bifalene cation $(\mathrm{MgCl} 2)$ : helps in efficient reactions. Function: enzymatic reaction cofactor when DNA polymerization takes place. PCR Buffer Function: maintain the $\mathrm{pH}$ balance of the solution during the amplification process. The PCR buffer consists of Tris- $\mathrm{HCl}$ and $\mathrm{KCl}$. Aquabidest (ddH2O) Function: as a solvent. Aquabidest is produced from water that is distilled twice, so it is purer than distilled water.

The thing that needs to be done before running is to add $130 \mathrm{ul}$ multiplex PCR master mix (blue cap tube) into the mericon assay tube (yellow cap tube), mix with pipetting or vortex then centrifuge for a few seconds. Dissolve positive DNA (red cap tube) add 200ul quantitec nucleic acid dilution buffer (black cap tube) vortex then centrifuge for a few seconds. Set up sample and reaction control as shown in Table 2 below:

Table 3. Set up RT- PCR Master mix

\begin{tabular}{|lccc|}
\hline Component & Sample & $\begin{array}{c}\text { Positive PCR } \\
\text { control }\end{array}$ & $\begin{array}{c}\text { Negative PCR } \\
\text { control }\end{array}$ \\
\hline $\begin{array}{l}\text { Reconstituted } \\
\text { mericon Assay }\end{array}$ & $10 \mu \mathrm{l}$ & $10 \mu \mathrm{l}$ & $10 \mu \mathrm{l}$ \\
$\begin{array}{l}\text { Sample DNA } \\
\text { Dissolved Positive } \\
\text { Control DNA }\end{array}$ & $10 \mu \mathrm{l}$ & - & - \\
$\begin{array}{l}\text { QuantiTect Nucleic } \\
\text { Acid Dilution Buffer } \\
\text { or RNase-free water }\end{array}$ & - & $10 \mu \mathrm{l}$ & - \\
\hline Total volume & $\mathbf{2 0 ~} \boldsymbol{\mu l}$ & $\mathbf{2 0} \boldsymbol{\mu l}$ & $\mathbf{2 0} \boldsymbol{\mu l}$ \\
\hline
\end{tabular}

Followed by running RT-PCR (Table 3) with the following settings:

Table 4. RT-PCR Running Rotor Gene 


\begin{tabular}{|lccl|}
\hline Step & Time & Temperature & Comments \\
\hline $\begin{array}{l}\text { Initial PCR } \\
\text { activation step }\end{array}$ & $5 \mathrm{~min}$ & $95^{\circ} \mathrm{C}$ & $\begin{array}{l}\text { Activation of HotStarTaq } \\
\text { Plus DNA polymerase }\end{array}$ \\
$\begin{array}{l}\text { 3-step cycling: } \\
\quad \text { Denaturation }\end{array}$ & $15 \mathrm{~s}$ & $95^{\circ} \mathrm{C}$ & Data collection at $60^{\circ} \mathrm{C}$ \\
$\quad \begin{array}{l}\text { Annealing } \\
\text { Extension }\end{array}$ & $15 \mathrm{~s}$ & $60^{\circ} \mathrm{C}$ & \\
Number of cycles & 45 & $72^{\circ} \mathrm{C}$ & \\
\hline Detection & Reporter & Excitation/emission & Channel \\
\hline Target & FAM & $495 / 520 \mathrm{~nm}$ & Green \\
Internal control & MAX & $524 / 557 \mathrm{~nm}$ & Yellow \\
\hline
\end{tabular}

\section{RESULTS AND DISCUSSION}

\section{The results of DNA analysis using a UV Spectrophotometer}

The results of DNA concentration and purity of sausage samples without MUI halal labels in Pandeglang Regency are shown in Table 1.

Table 1. Results of concentration and purity of sausage DNA samples without halal labels

\begin{tabular}{llll}
\hline No & Sample & $\begin{array}{c}\text { Concentration } \\
(\mathrm{ng} / \mu \mathrm{l})\end{array}$ & $\begin{array}{l}\text { Purity } \\
\left(\mathrm{A}_{260} / \mathrm{A}_{280}\right)\end{array}$ \\
\hline 1. & Sample 1 & 74,4 & 1,9 \\
2. & Sample 2 & 53,5 & 1,84 \\
3. & Sample 3 & 69,5 & 1,86 \\
4. & Sample 4 & 102,5 & 1,84 \\
5. & Sample 5 & 40 & 1,9 \\
6. & Sample 6 & 37,8 & 1,9 \\
\hline
\end{tabular}

The results of the isolation of 6 samples representing 10 sausage samples without the halal logo at the hawker center in the Pandeglang Regency resulted in the concentration and purity of DNA measured using a UV Vis Spectrophotometer with a wavelength of $260 \mathrm{~nm}$ and $280 \mathrm{~nm}$. Measurement of DNA concentration and purity using a UV Vis Spectrophotometer based on the principle of irradiating ultraviolet light which is absorbed by nucleotides and proteins in solution (Muladno 2010).

Table 6 shows the concentration of the resulting samples ranged from 37.8 to 102.5 $\mathrm{ng} / \mu \mathrm{l}$, respectively. Sample number 6 has the lowest concentration value $37.8 \mathrm{ng} / \mu$ l while sample number 4 has the highest concentration value $102.5 \mathrm{ng} / \mu \mathrm{l}$. From the purity results with this concentration, it can still be continued to analysis using RT-PCR. The minimum concentration limit to proceed to RT-PCR is $0.30-0.80 \mathrm{pg}$ (Adreo et al. 2005). 
The purity values produced from the sausage samples ranged from 1.84 to 1.9 (A260 / A280). The ratio between $260 \mathrm{~nm}$ and $280 \mathrm{~nm}$ wavelengths is the value of DNA purity. The value of DNA purity in the samples carried out by Muladno (2010) ranged from 1.8 to 2.1 using RT-PCR. The purity results showed no protein contamination (concentrations below $1.8)$.

\section{Amplification results using RT PCR}

The amplification curve analysis of the curve and the $\mathrm{Cp}$ (Crossing point) value can be seen through the melting point $(\mathrm{Tm})$ on the melting curve. $\mathrm{Cp}$ is the number of cycles in which the sample begins to read above the Arbitary Fluorescence Level (AFL) which indicates the onset of the exoponential growth phase (Roche 2008). The lower the Cp value, the higher the target DNA concentration value. Tm is the temperature at which $50 \%$ of the DNA opens, becoming single strands. The value of Tm depends on the base of Adenine (A), Guanine (G), Thymine (T) and Citosin (C) (Izzah 2014). Figure 1 and Figure 2 show the Cp and Tm values of 6 sausage samples in 6 sub-districts in Pandeglang Regency.

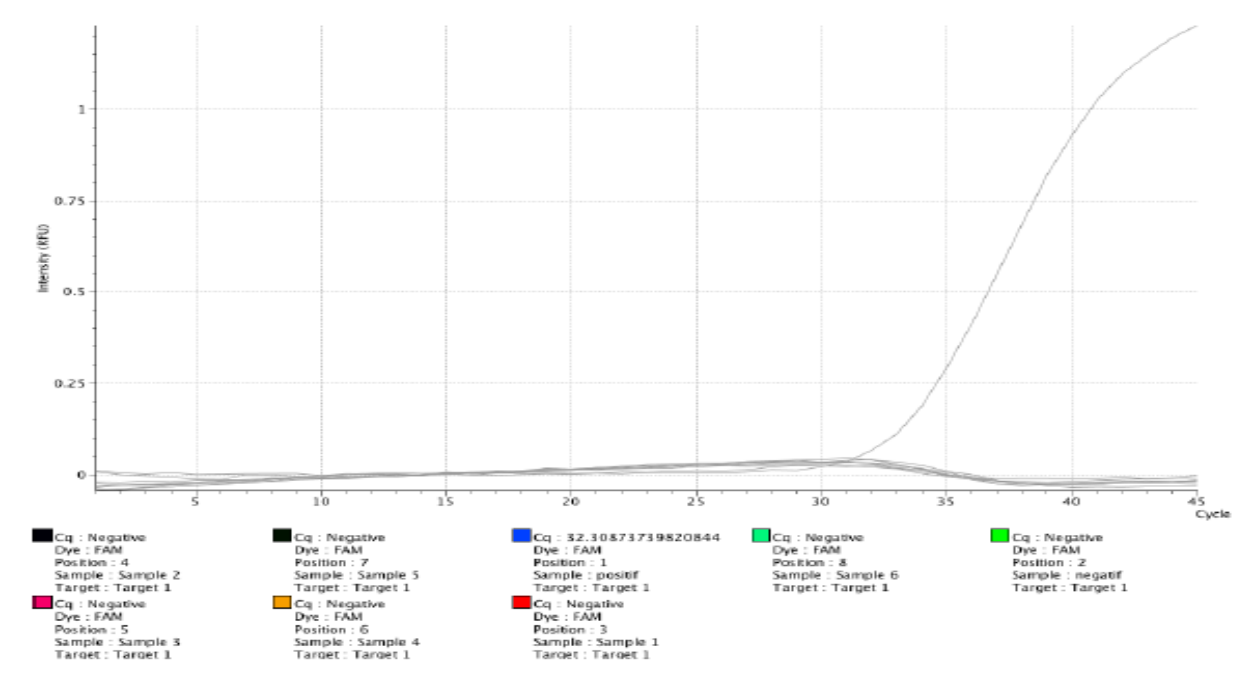

Figure 1. Amplification curve of 6 sausage samples in 6 sub-districts in Pandeglang Regency

The data showed that the results of analysis using RT PCR on samples 1 to 6 did not contain pig DNA. This is indicated by the absence of an amplification curve on the FAM channel. The Cp results for four sausage samples in the district of Pandeglang Regency resulted in a value of 27.55 - 28.61 which was close to the $\mathrm{Cp}$ value of negative control beef sausage DNA (Rostianti et al. 2020).

The only amplification curve on the FAM channel is positive control. The PCR process is running well, this can be seen from the cq value of the VIC channel on all samples and controls - and + has a value of cq $30-31.29$ (Table 2). 

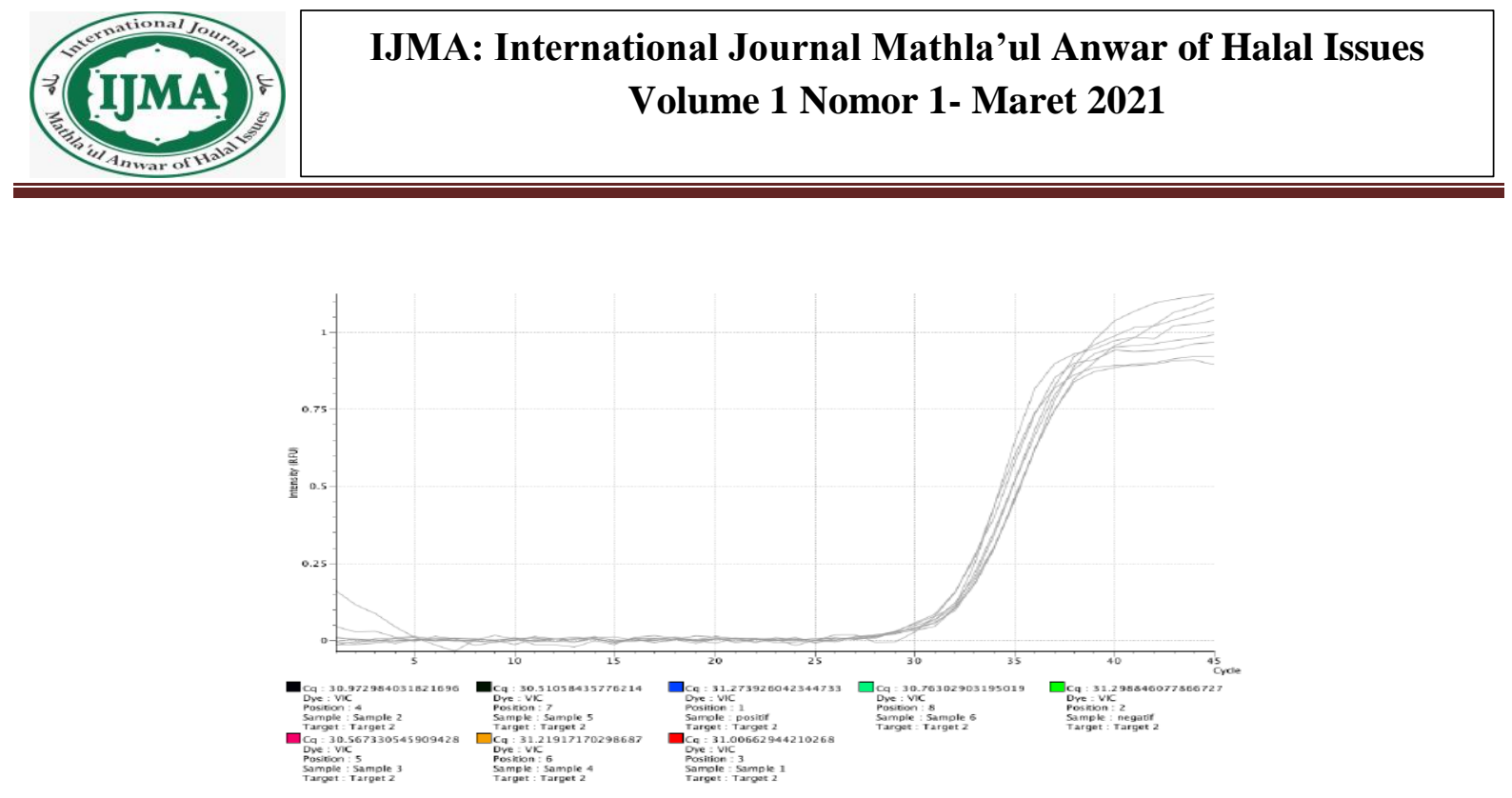

Figure 2. Melting curve of 6 sausage samples

From Table 2, the Cq FAM value can only be seen in positive swine DNA samples, this proves that all sausage samples tested negative were not contaminated with pork.

Table 2. Cq value for 6 sausage samples

\begin{tabular}{|c|c|c|c|c|c|c|c|c|c|}
\hline Pos. Note & Sample & FAM & Type & $\mathrm{Cq}_{\mathrm{q}}$ & + Quantity & nc & Type & $\mathrm{Cq}_{\mathrm{q}}$ & + Quantity \\
\hline 1 & $D_{\text {positif }}$ & Target 1 & [0 & 32.31 & $\checkmark$ & DTarget 2 & 旬 & 31.27 & $\checkmark$ \\
\hline 2 & $\square_{\text {negatf }}$ & Target 1 & N & & & DTarget 2 & W & 31.3 & $\checkmark$ \\
\hline 3 & Dsample 1 & Target 1 & 匹 & & & $\Gamma_{\text {Target } 2}$ & 0 & 31.01 & $\checkmark$ \\
\hline 4 & Sample 2 & Target 1 & ๒ & & & DTarget 2 & 0 & 30.97 & $\checkmark$ \\
\hline 5 & Sample 3 & Target 1 & ए & & & Target 2 & 0 & 30.57 & $\checkmark$ \\
\hline 6 & DSample 4 & Target 1 & ๘] & & & $\square_{\text {Target } 2}$ & 0 & 31.22 & $\checkmark$ \\
\hline 7 & Sample 5 & DTarget 1 & [u & & & DTarget 2 & 旬 & 30.51 & $\checkmark$ \\
\hline 8 & 口Sample 6 & Drarget 1 & 四 & & & DTarget 2 & 旬 & 30.76 & $v$ \\
\hline
\end{tabular}

\section{CONCLUSION}

Real Time Polymerase Chain Reaction (RT PCR) is a instrument to accurately detect and has a high sensitivity to detect whether or not pig DNA is contaminated in processed food. RT PCR can also detect very large samples in a real time.

The results of the DNA purity test on sausage samples in the Pandeglang Regency had DNA purity values from 1.84 to 1.9 (A260 / A280) and resulted in sample concentrations ranging from 37.8 to $102.5 \mathrm{ng} / \mu 1$. The only amplification on the FAM curve was only in the positive control pigs, the Cq values ranged from 30 - 31.29.

The results of the RT PCR on sausage samples in the sub-district area in Pandeglang Regency did not detect the presence of pig DNA content, this was indicated by the absence of an amplification curve on the FAM channel. 


\section{ACKNOWLEDGEMENT}

Many thanks to the Ministry of Education and Culture of the Directorate of Higher Education of the Republic of Indonesia for the 2020 Penelitian Dosen Pemula (PDP) Grants Fund.

\section{REFERENCES}

Adreo, Mario L, Lauro L, Puyet A. 2005. Identification and quantification in species of complex DNA. Mixture by Real Time Polymeraase Chain Reaction. Analytical Biochemistry 339 (1): 73-82

Amqizal HIA, Al-Kahtani HA, Ismail EA, Hayat K, Jaswir I. 2017. Identification and Verification of Porcine DNA in Comercial Gelatin and Gelatin Containing Processing Foods. Food Control Journal Vol 78: 297-303.

Cai H, Gung X, Scnalan MS, Ramatlapeng DH, Lively CR. 2012. Real Time PCR Assay for Detection and Quantitation of Porcine and Bovine DNA in Gelatin Mixture in Gelati Capsule. Journal of Food Composition and Analysisi, 25: 83-87.

Izzah, Afifah N. 2014. Perbandingan antara metode SYBR Green dan metode hidrolisis Probe dalam analisa DNA Gelatin sapi dan DNA gelatin babi menggunakan RT PCR.. UIN Syarif Hidayatullah. Jakarta.

Kamaliah K. 2017. Perbandingan Metode Ekstraksi DNA Phenol-Chloroform dan Kit Extraction pada Sapi Aceh dan Sapi Madura. Biotik: Jurnal Ilmiah Biologi Teknologi dan Kependidikan, 5(1), 60-65.

Millani RN, Suharti N, Asterina A. 2016. Uji Mikroorganisme pada Cabai (Capsicum апnиum) Bakso yang Disajikan di Tempat Penjualan Bakso di Kecamatan Padang Timur. Jurnal Kesehatan Andalas, 5(3).

Muladno. 2010. Teknologi Rekayasa genetik. Edisi ke 2. IPB Press Bogor.

Roche. 2008. The Light Cycler ${ }^{(\mathrm{R})} 480$ Instrumen Operators Manual.

Rostianti TM, Susilo H, Indriati M, Suhaemi. 2020. Detection Of Pig DNA Contamination with RT-PCR in Sausage without halal labels from district Pandeglang. Gorontalo Agriculture Technology Journal, Vol 2 (3): 72-80

Sugiyono. 2005. Memahami penelitian kuanitatif. Bandung, Alfabeta. 